Relationship between local changes in cortical blood flow and extracellular $\mathrm{K}+$ during spreading depression.

Quistorff, Bjørn; Hansen, Anker Jon; Gjedde, Albert

Published in:

Acta Physiol Scand*

Publication date:

1980

Document version

Publisher's PDF, also known as Version of record

Citation for published version (APA):

Quistorff, B., Hansen, A. J., \& Gjedde, A. (1980). Relationship between local changes in cortical blood flow and extracellular $\mathrm{K}^{+}$during spreading depression. Acta Physiol Scand ${ }^{*}$, 109(1), 1-6. 


\title{
Relationship between local changes in cortical blood flow and extracellular $\mathrm{K}^{+}$during spreading depression*
}

\author{
ANKER JON HANSEN, ${ }^{1}$ BJØRN QUISTORFF”' and ALBERT GJEDDE' \\ Institutes of 'Medical Physiology, Department $A$, and "Biochemistry, Department A, \\ University of Copenhagen, Denmark
}

\begin{abstract}
HANSEN, A. J., QUISTORFF, B. \& GJEDDE, A.: Relationship between local changes in cortical blood flow and extracellular $\mathrm{K}^{+}$during spreading depression. Acta Physiol Scand 1980, 109: 1-6. Received 19 June 1979. ISSN 0001-6772. Institutes of Medical Physiology, Dept. A, and Biochemistry, Dept. A, University of Copenhagen, Denmark.

Change of local cerebral blood flow in response to a single cortical spreading depression of Leão was studied in the brain. During a spreading depression, potassium briefly accumulates in the brain extracellular space. The cortical blood flow was normal during the maximal rate of increase of the extraceliular potassium concentration. The blood flow doubled during the subsequent period of normalization of potassium and remained high for one minute thereafter. Thus, potassium cannot be the immediate mediator of the blood flow increase.
\end{abstract}

Key words: Spreading depression, cerebral blood flow, brain extracellular potassium concentration, metabolic autoregulation of blood flow

Leão's cortical spreading depression (CSD) of EEG (Leão 1944a) is generalized response of the cerebral cortex of animals and man to a variety of noxic influences, chemical, electrical, and mechanical stimuli (Bureš et al. 1974, Šramka et al. 1977).

The CSD is accompanied by localized changes of the extracellular concentrations of potassium, sodium, chloride, and calcium (Hansen 1979, Kraig \& Nicholson 1978, Nicholson \& Kraig 1975 , Nicholson et al. 1977, Vyskočil et al. 1972). The perturbation moves from the site of elicitation at a speed of approximately $3 \mathrm{~mm} / \mathrm{min}$ (Bureš et al. 1974).

The response of the cerebral circulation to the passage of spreading depression was studied by Leão (1944b), Burešova (1957), Tschirgi et al. (1957), and Van Harreveld \& Ochs (1957), all of whom observed dilatation of pial vessels preceeded by moderate constriction. From indirect evidence, Van Harreveld \& Stamm (1952) deduced the presence of vascular constriction early in the course of the events that constitute CSD. The absolute magnitude of the local cerebral blood flow changes during CSD has never been reported, nor is the exact temporal relationship between ion concentration changes and cerebral blood flow known.
Since the changes of flow may be related to the extracellular potassium concentration $\left(\left[\mathrm{K}^{+}\right]_{e}\right)(\mathrm{Ku}-$ schinsky \& Wahl 1978), we investigated the relationship between $\left[\mathrm{K}^{+}\right]_{\mathrm{e}}$ and local blood flow.

\section{METHODS}

Male Wistar rats, in average weighing $360 \mathrm{~g}$, were anesthetized with an initial dose of pentobarbital $\left(50 \mathrm{mg} \mathrm{kg} \mathrm{kg}^{-1}\right)$ and supplementary doses as required later. Catheters were placed in the femoral arteries and one femoral vein. The spontaneously breathing rats were placed in a head holder and the parietal bones removed by craniotomy.

The experiments were performed as outlined in Fig. 1. Following respiratory steady-state, a single CSD was elicited from the cortex with a brief stab by a hypodermic needle through a small burr hole in the left frontal bone. The advance of the CSD was monitored with two doublebarrelled potassium-sensitive microelectrodes with tip diameters of $1-2 \mu \mathrm{m}$. The microelectrodes were passed through the intact dura and placed in the extracellular space of the left parietal cortex at a depth of approximate-

\footnotetext{
* Presented in part at the meeting of the Scandinavian Physiological Society, Odense, Denmark, November 1978 (Quistorff et al. 1979), and the Symposium on Cerebral Metabolism and Neural Function, U.S. National Institute of Neurological and Communicative Disorders and Stroke, Bethesda, Maryland, May 1979 (Gjedde et al., 1980b).
} 


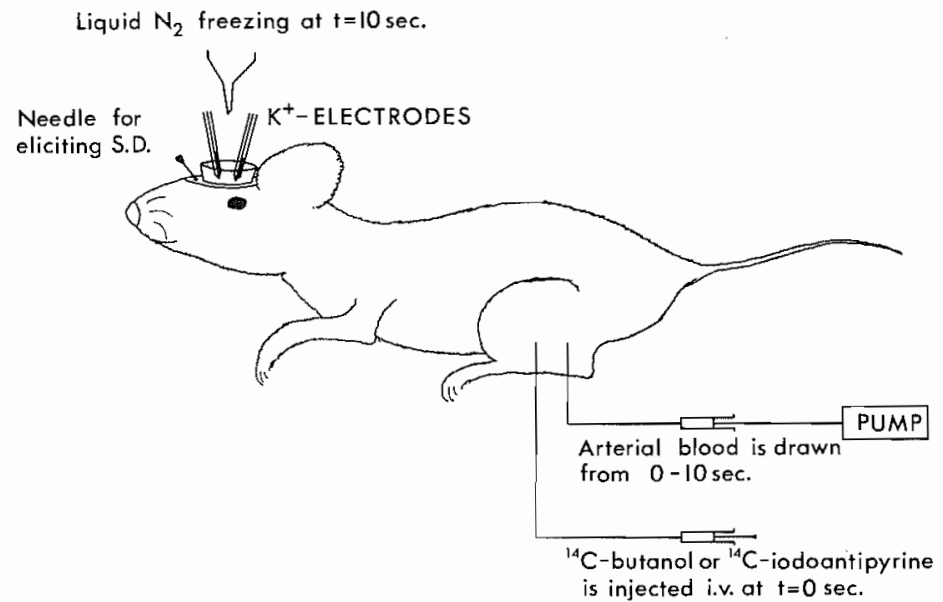

Fig. 1. Experimental design. A single cortical spreading depression (CSD) was elicited by a needle stab in the left frontal cortex. The advance of the CSD was followed by two potassium-sensitive microeletrodes placed in the left parietal cortex. Approximately 30 $s$ after the initial increase of $\left[\mathrm{K}^{+}\right]_{\mathrm{e}}$ observed at the posterior electrode, regional cerebral blood flow was determined by bolus injection of either $\left[{ }^{14} \mathrm{C}\right]$ butanol or $\left[{ }^{14} \mathrm{C}\right]$ iodoantipyrine into a femoral vein and sampling of arterial blood. The left and right parietal cortices, covered by intact dural membrane, were frozen by application of liquid nitrogen after $10 \mathrm{~s}$.

ly $0.5 \mathrm{~mm}$ (Hansen 1977). As the anterior-posterior distance between the electrodes was 3-4 mm, the CSD-wave travelled between the electrodes in one minute (the right parietal cortex was also exposed, but no electrodes were inserted).

In order to visualize the blood flow change accompanying the CSD, as well as to quantify the absolute blood flow rate, the tissue was freeze-clamped and the distribution of blood flow was measured by autoradiography and by liquid scintillation counting of small tissue samples.

Approximately $30 \mathrm{~s}$ after the initial change of $\left[\mathrm{K}^{+}\right]_{\mathrm{e}}$ detected at the posterior electrode, we injected a $200 \mu \mathrm{l}$ i.v. bolus of $250 \mu \mathrm{Ci} \mathrm{kg}^{-1} 4-[N$-methyl-14 $\mathrm{C}]$-iodoantipyrine for autoradiography (2 rats) or $10 \mu \mathrm{Ci} \mathrm{kg}^{-1} \mathrm{n}-\left[1-^{14}\right.$ C]butanol for tissue sampling (8 rats), and arterial blood sampling was started simultaneously. The arterial blood was sampled for $10 \mathrm{~s}$ at a known and constant rate by a syringe attached to a Harward withdrawal pump. At the end of this blood collection, arrest of the cortical circulation in situ was produced by generous application of liquid nitrogen to the exposed dura overlying the parietal cortex. Since only a $0.2 \mathrm{~mm}$ wide cleft separates the dural surface from the arteries and veins situated at the surface of the cortex or in the subarachroid space, freezing of the blood in the vessels supplying and draining the cortex, and thus arrest of the cortical circulation, can be estimated from the results of Quistorff (1980) who showed that the temperature of rat cortical tissue at a distance of $0.7 \mathrm{~mm}$ from a coolant with a ternperature of less than $-150^{\circ} \mathrm{C}$ will fall from $37^{\circ} \mathrm{C}$ to $0^{\circ} \mathrm{C}$ in $0.8 \mathrm{~s}$. It may therefore be estimated that arrest of the cortical circulation was achieved about $1 \mathrm{~s}$ after application of the nitrogen and the termination of the collection of blood in the syringe. A delay of a few seconds in the arrest of the cortical circulation would lead to a fall in $E(T)$, cf. below, for butanol or iodoantipyrine of a few per cent and thus to an underestimation of blood flow of similar magnitude. However, in that case the arterial sample collection would have been stopped before the moment of arrest of cortical circulation and the blood flow therefore overestimated, due to insertion of a too low value for $Q_{0}(T)$ in eq. (1). Thus, the two errors introduced by delayed freezing tend to cancel. The observed blood flow rates (see later) corresponded very closely to the blood flow rates observed by the same technique in similarly prepared, but decapitated rats (Sage \& Duffy 1979).

Autoradiography for determination of local cerebral blood flow by laballed iodoantipyrine was performed as follows: The frozen brain was removed from the skull under liquid nitrogen and prepared for sectioning in a cryostat at $-22^{\circ} \mathrm{C}$. The parietal cortex was divided into 20 $\mu \mathrm{m}$ tangential sections. Every fifth section was placed on glass slides and rapidly dried on a hot-plate $\left(60^{\circ}\right)$. The dried sections were placed face down on the emulsioncoated side of a Kodak Nuclear Medical Blue X-ray film for four days.

The autoradiographic density was measured, using brain cortex sections containing a known amount of isotope for calibration. Identical $0.5 \mathrm{~mm}$ brain sections were cut with a string knife (Franck et al. 1967) and small chunks (about $20 \mathrm{mg}$ ) placed in five test tubes containing mock-CSF with addition of different amount of $\left[{ }^{14} \mathrm{C}\right]-$ iodoantipyrine. After $30 \mathrm{~min}$ the isotope was in equilibrium with the entire slice. Twenty $\mu \mathrm{m}$ slices were then cut in a cryostat and some were rapidly dried for densitometry, while others were weighed and counted by liquid 
Table 1. Physiological variables of rats included in the present study

\begin{tabular}{ll}
\hline Variable & Mean \pm S.E. \\
\hline $\mathrm{PaO}_{2}$ (mmHg) & $95 \pm 3$ \\
$\mathrm{PaCO}_{2}$ (mmHg) & $36 \pm 1$ \\
Arterial pH & $7.41 \pm 0.02$ \\
$\mathrm{MABP}^{a}$ (mmHg) & $109 \pm 5$ \\
\hline
\end{tabular}

a Mean arterial blood pressure. Number of observations $=10$.

scintillation spectrometry. Films of standard and experimental sections were processed in a Beckman densitometer with a beam aperture of $0.2 \mathrm{~mm}^{2}$.

Tissue sampling for determination of regional cerebral blood flow by labelled butanol was performed as follows: The frozen brain was divided into $1.2 \mathrm{~mm}$ thick coronal slices by an electric saw in a glove box at $-25^{\circ} \mathrm{C}$ (Quistorff 1975). The $5 \mathrm{~mm}$ wide bits of cortical tissue was isolated, weighed, and prepared for liquid scintillation counting, as was the arterial sample.

The blood flow of the cortical regions was calculated as described previously (Gjedde et al. 1980 $a$ ) from tissue and arterial blood sample contents of labelled butanol or labelled iodoantipyrine, using an equation relating the integrated in- and efflux rates of butanol in brain,

$\mathrm{f}^{\mathrm{bl}}=\frac{1}{\mathrm{E}(\mathrm{T})} \mathrm{F}_{0}^{\mathrm{bl}} \frac{\mathrm{C}_{\mathrm{br}}(\mathrm{T})}{\mathrm{Q}_{0}(\mathrm{~T})}$

in which $E(T)$ is the net cerebral extraction fraction of radioactive tracer in time $T$ after the introduction of the indicator into the circulation, $F_{0}^{\text {bl }}$ the constant rate of collection of arterial blood, $Q_{0}(T)$ the amount of radioactive tracer collected, and $C_{b r}(T)$ the amount of indicator per unit weight of a sample of brain to which $\mathrm{f}^{\mathrm{tl}}$ refers.

The use of eq. (1) requires that two criteria are fulfilled: (1) that the time integrals of internal carotid and femoral arterial concentrations of tracer from injection to arrest of cortical circulation are equal, and (2) that efflux of tracer from brain is negligible in the $10 \mathrm{~s}$ and that, therefore, $\mathrm{E}(10 \mathrm{~s})=1$ may be used as a good approximation .

With regard to the first criterion, Gjedde et al. (1980a) showed that the integral was independent of the site of sampling from 3 to $30 \mathrm{~s}$ after injection of the tracer.

The second criterion was confirmed by Gjedde et al. (1980a) for butanol and by Sakurada et al. (1978) for iodoantipyrine by comparison of cerebral blood flow values calculated with these indicators with values measured directly on the basis of arterial and venous concentrations or by means of inert gases of known, essentially infinite, permeability in the blood-brain barrier.

In addition, Crone (1965) showed that the extraction fraction of butanol, integrated from the time of appearance of an intracarotid bolus in cerebral venous blood to a time $5 \mathrm{~s}$ later averaged 0.96 in the dog.

The criteria were confirmed in a rat in which the net extraction fraction of butanol in $10 \mathrm{~s}$ was measured directly by simultaneous sampling of blood from both
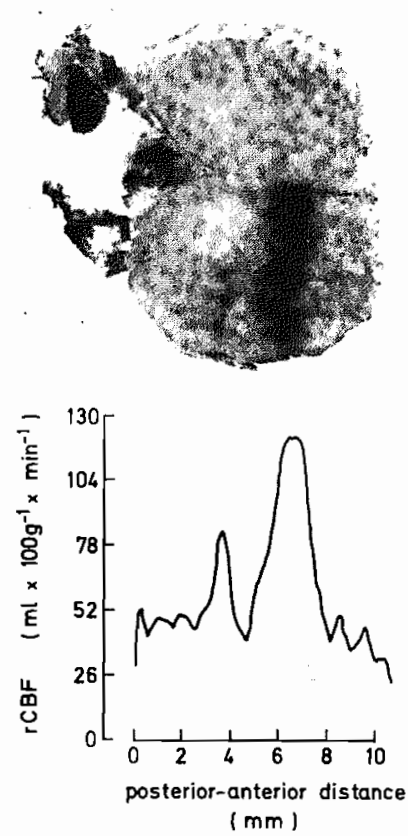

Fig. 2. Upper panel: Autoradiogram of tangential (horizontal) $20 \mu \mathrm{m}$ section of rat brain parietal cortex, cut at a depth of $0.5 \mathrm{~mm}$. A single spreading depression was elicited in the left hemisphere. The cortex was frozen in situ by application of liquid nitrogen, ten seconds after an i.v. bolus injection of labeled iodoantipyrine. The frozen cortex was cut in a cryostat and the sections placed on an $\mathrm{X}$-ray film for 4 days. The lower part of the autoradiogram represents the left parietal cortex. The spreading depression moved from the right (anterior) part of the section to the left (posterior) one. For $E(T) \sim 1$, the radioactivity of the sample, i.e. the grain density, is linearly proportional to the local blood flow, as shown in eq. (1).

Lower panel: Densitometric scan through the left hemisphere of the autoradiogram shown in the upper panel. Densities were converted to blood flow rates by the procedure described in the text.

femoral arteries, one external carotid artery, and the superior sagittal sinus of the brain. The amounts of tracer recovered in the superior sagittal sinus and external carotid samples in the $10 \mathrm{~s}$ from injection represented $6.5 \%$ and $98.3 \%$, respectively, of the average amount collected in the femoral samples.

\section{RESULTS}

The physiological variables of the animals are given in Table 1. The autoradiographs (Fig. 2, upper panel) revealed a remarkable picture: An approximately $2 \mathrm{~mm}$ wide, well-defined band of increased density on the hemisphere where the CSD wave progressed. The wide band of increased density 


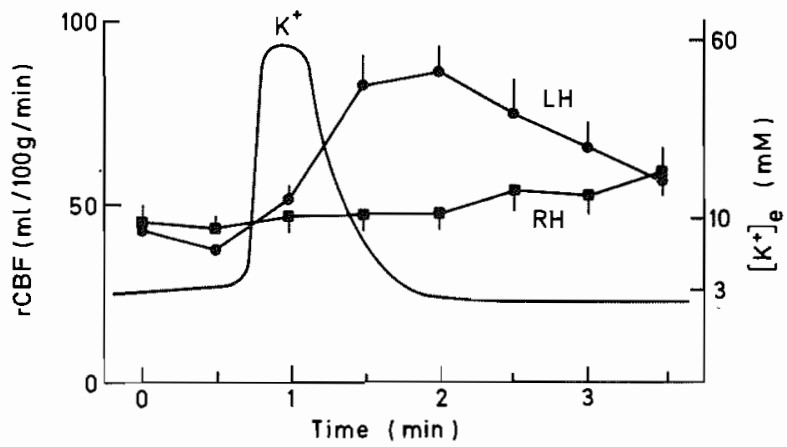

Fig. 3. Changes of extracellular potassium concentration and regional cerebral blood flow (rCBF) of $3 \mathrm{mg}$ samples of rat brain parietal cortex during a single cortical spreading depression in the left hemisphere. The cortex was frozen in situ by application of liquid nitrogen, $10 \mathrm{~s}$ after an intravenous bolus injection of radioactive butanol. The frozen brain was cut in $1.2 \mathrm{~mm}$ thin coronal sections and prepared for liquid scintillation spectrometry. The local blood flow was calculated from the radioactivity of each sample. The progression of the parietal spreading depression was monitored by potassium-sensitive microelectrodes placed in the cortex of the left hemisphere. From the width of the cortical slices, and assumption of uniform speed of progression corresponding to that observed between the electrodes, spatial flow events were converted to temporal events at the site of one electrode. The trace marked $\mathrm{K}^{+}$shows the changes of extracellular potassium concentration at one electrode in the left parietal cortex. The curve marked LH represents the calculated change of blood flow at the same electrode. The curve marked RH represents the change of blood flow at a corresponding site in the right parietal cortex. The bars represent one standard error of the mean.

was preceeded by a similarly dense but narrow band. These areas were separated by a somewhat wider band of normal density. The zones of increased density transected the entire cortex.

Close examination of the autoradiographs revealed a dotted pattern of increased density in the unaffected cortical regions of the left hemisphere as well as in the cortical regions of the right hemisphere (Fig. 2, upper panel). The dots measured approximately $0.4 \mathrm{~mm}$ in diameter and probably reflect the presence of cortical columns (Hubel \& Wiesel 1962, Mountcastle 1957, Sokoloff et al. 1977).

The result of the quantitation procedure is shown in the lower panel of Fig. 2. Calculated values for cortical blood flow in the undisturbed parietal cortex varied between 50 and $40 \mathrm{ml}(100 \mathrm{~g})^{-1} \mathrm{~min}^{-1}$, the variations corresponding to areas of different densities. The scanner aperture of $0.2 \mathrm{~mm}^{2}$ led to understimation of the differences in flow in areas with steep density gradients.

The local blood flow determined by labelled butanol contents in tissue samples confirmed the picture obtained from the autoradiographs (Fig. 3). However, the initial narrow band of increased blood flow could not be detected, probably because the lengthwise resolution power of the tissue sampling methods was lower than that of the autoradiogram-scanning method (approximately $1.2 \mathrm{~mm}$ versus $0.5 \mathrm{~mm}$ ).

The observation that the flow of the undisturbed cortex was $50 \%$ of the flow normally observed in rat cortex reflected the barbiturate anesthesia (Gjedde et al. $1980 b$, Nilsson \& Siesjö 1975). Close scrutiny of the relationship between the $\left[\mathrm{K}^{+}\right]_{\mathrm{e}}$ and cortical blood flow revealed the presence of three phases: Initially, the $\left[\mathrm{K}^{+}\right]_{\mathrm{e}}$ increased to $60 \mathrm{mM}$ while the cortical blood flow remained unchanged. During the second phase, cortical blood flow increased to twice the normal value while $\left[\mathrm{K}^{+}\right]_{\mathrm{e}}$ returned to $3 \mathrm{mM}$. During the final phase, which lasted about one minute, cortical blood flow decreased to its previous level and no further change of $\left[\mathrm{K}^{+}\right]_{\mathrm{e}}$ was noticed.

\section{DISCUSSION}

The present study demonstrates for the first time the marked change in cerebral blood flow occurring during a single CSD in the rat. The CSD represents 
a phenomenon in which significant variations of $\left[\mathrm{K}^{+}\right]_{\mathrm{e}}$ and blood flow occur in the cerebral cortex. Therefore, the phenomenon is ideally suited for a study of the relationship between the two variables. A prerequisite for this study was the development of a method which can detect rapid flow changes (Gjedde et al. 1980 $a$ ).

It is evident from the present study that high cerebral blood flow was not directly associated with the increased $\left[\mathrm{K}^{+}\right]_{\mathrm{e}}$ but rather with the subsequent reduction of $\left[\mathrm{K}^{+}\right]_{\mathrm{e}}$. It is well known that increased cerebral blood flow is coupled to increased metabolic activity in the brain (Reivich et al. 1975) and that high $\left[\mathrm{K}^{+}\right]_{\mathrm{e}}$ stimulates the metabolic rate of nervous tissue (Ashford \& Dixon 1935, Hertz \& Clausen 1963, Lothman et al. 1975, Shinohara et al. 1979). Thus, it is likely that the effect of increased $\left[\mathrm{K}^{+}\right]_{\mathrm{e}}$ on cerebral blood flow is mediated through metabolic factors that may be related to increased ion pumping in connection with the return of potassium to the intracellular compartment (Quistorff et al. 1979). The metabolic factor(s) that constitute(s) the link between metabolism and flow remain(s) to be identified.

In the past, several factors, including $\mathrm{O}_{2}, \mathrm{H}^{+}, \mathrm{K}^{+}$, and adenosine, have been implicated in metabolic autoregulation. However, it has not been possible to demonstrate parallel changes of any of these factors in all the conditions of increased blood flow investigated (Astrup et al. 1976, Leniger-Follert \& Lübbers 1979, Rubio et al. 1975).

The flow variations during a CSD can partially be explained by an action of potassium itself on cerebral vessels. It has been shown that an increase of $\left[\mathrm{K}^{+}\right]_{\mathrm{e}}$ up to $10 \mathrm{mM}$ caused dilatation of pial vessels while further increases lead to constriction (Kuschinsky \& Wahl 1978). Thus, a marked transient increase of $\left[\mathrm{K}^{+}\right]_{\mathrm{e}}$ would initially induce dilatation of cerebral vessels, followed by a vasoconstriction; subsequently cellular re-uptake of $\mathrm{K}^{+}$(and extrusion of $\mathrm{Na}^{+}$(Hansen 1979)) could give rise to a metabolically-induced vasodilation. This succession of events was actually observed in the autoradiographs obtained in this study. Thus, the first peak of increased density corresponds to the initial increase of $\left[\mathrm{K}^{+}\right]_{\mathrm{e}}$, followed by vasoconstriction (the intermediate band of decreased density), ending in a marked longer lasting vasodilatation, duing which $\mathrm{K}^{+}$is pumped back into the cells.

The present data suggest that the major perturbation of cerebral blood flow occurs after the wave of
$\left[\mathrm{K}^{+}\right]_{\mathrm{e}}$ increase. The cellular events immediately preceding the changes of extracellular ion concentrations during CSD are still unknown.

Supported by grants 512-8173 (Albert Gjedde) and 51215355 (Albert Gjedde and Anker Jon Hansen) from the Medical Research Council, Denmark. The authors wish to thank Lissi Immerdal, Ellen Munch, and Marianne Anker Sørensen for expert technical assistance, and Berit Ree and Hildegard Mosthaf for preparation of the manuscript. Chief Radiographer Marion May, Department of Radiology, University Hospital (Rigshospitalet), kindly assisted with the autoradiography.

\section{REFERENCES}

ASHFORD, C. A. \& DIXON, K. C. 1935. The effect of potassium on the glycolysis of brain tissue with reference to the Pasteur effect. Biochem J 29: 157-168.

ASTRUP, J., HEUSER, D., LASSEN, N. A., NILSSON, B., NORBERG, K. \& SIESJÖ, B. K. 1976. Evidence against $\mathrm{H}^{+}$and $\mathrm{K}^{+}$as the main factors in the regulation of cerebral blood flow during epileptic discharges, acute hypoxemia, amphetamine intoxication, and hypoglycemia. A microelectrode study. In: Ionic actions on vascular smooth muscle (ed. E. Betz), p. 110. Springer, Berlin, Heidelberg and New York.

BUREŠ. J., BUREŠOVA, O. \& KŘIVÁNEK, J. 1974. The mechanism and applications of Leao's spreading depression of encephalographic activity. Academic Press, New York.

BUREŠOVA, O. 1957. Changes in cerebral circulation in rats during soreading EEG depression. Physiol Bohemoslov 6: 1-10.

FRANCK, G., CORNETTE, M. \& SCHOFFENIELS, E. 1968. The cationic composition of incubated cerebral cortex slices. J Neurochem 15: 843-847.

GJEDDE, A., HANSEN, A. J. \& SIEMKOWICZ, E. $1980 \mathrm{a}$. Rapid simultaneous determination of regional blood flow and blood-brain glucose transfer in brain of rat. Acta Physiol Scand 108: 321-330.

GJEDDE, A., HANSEN, A. J. \& SIEMKOWICZ, E. $1980 \mathrm{~b}$. Rapid simultaneous determination of regional cerebral blood flow and blood-brain glucose transfer in rats. In: Cerebral metabolism and neural function. Williams and Wilkins, Baltimore. In press.

HANSEN, A. J. 1977. Extracellular potassium concentration in juvenile and adult rat brain cortex during anoxia. Acta Physiol Scand 99: 412-420.

HANSEN, A. J. 1979. Brain extracellular ions in ischemia and spreading depression. Acta Physiol Scand, Suppl. 473:58.

HERTZ, L. \& CLAUSEN, T. 1963. Effects of potassium and sodium on respiration: Their specificity to slices from certain brain regions. Biochem J 89:526633.

HUBEL, D. H. \& WIESEL, T. N. 1962. Receptive fields, binocular interaction, and functional architecture in the cat's visual cortex. J Physiol (Lond.) 160: $106-154$. 
KERR, S. E. 1935. Studies of phosphorous compounds of the brain. J Biol Chem 110:625-635.

KRAIG, R. P. \& NICHOLSON, C. 1978. Extracellular ionic variations during spreading depression. Neuroscience 3: 1045-1059.

KUSCHINSKY, W. \& WAHL, M. 1978. Local chemi$\mathrm{cal}$ and neurogenic regulation of cerebral vascular resistance. Physiol Rev 58: 656-689.

LEĀO, A. A. P. $1944 a$. Spreading depression of activity in cerebral cortex. J Neurophysiol 7:359-390.

LEĀO, A. A. P. 1944b. Pial circulation and spreading depression of activity in the cerebral cortex. J Neurophysiol 7: 391-396

LENIGER-FOLLERT, E. \& LÜBBERS, D. W. 1979. Significance of local tissue $\mathrm{PO}_{2}$ and of extracellular cations for functional and reactive hyperemia of microcirculation in the brain. In: Brain and heart infarct II (ed. K. J. Zülch, W. Kaufmann, K.-A. Hossman \& V. Hossman), pp. 193-201. Springer Verlag, Berlin, Heidelberg and New York.

LOTHMAN, E., LaMANNA, J., CORDINGLEY, G., ROSENTHAL, M. \& SOMJEN, G. 1975. Responses of electrical potential, potassium levels, and oxidative metabolic activity of the cerebral neocortex of cats. Brain Res 88: 15-36.

MOUNTCASTLE, V. B. 1957. Modality and topographic properties of single neurons of cat's somatic sensory cortex. J Neurophysiol 20:408-434.

NICHOLSON, C. \& KRAIG, R. P. 1975. Chloride and potassium changes measured during spreading depression in the catfish cerebellum. Brain Res 96: 384-389.

NICHOLSON, C., ten BRUGGENCARTE, G., STEINBERG, R. \& STÖCKLE, H. 1977. Calcium modulation in brain extracellular microenvironment demonstrated with ion-selective micropipette. Proc Natl Acad Sci (USA) 74: 1287.

NILSSON, B. \& SIESJÖ, B. K. 1975. The effect of phenobarbitone anaesthesia on blood flow and oxygen consumption in the rat brain. Acta Anaesth Scand, Suppl. 57: 18-24.

PONTÉN, U., RATHESON, R. A., SALFORD, L. G. \& SIESJÖ, B. K. 1973. Optimal freezing conditions for cerebral metabolites in rats. J Neurochem 21: 1127-1138.

QUISTORFF, B. 1975. A mechanical device for the rapid removal and freezing of liver or brain tissue from unanesthetized and non-paralyzed rats. Anal Biochem 68: 102-119.

QUISTORFF, B. 1980. Guillotine-freeze-clamping of rat brain in vivo. Analysis of energy metabolites along the freezing gradient. In: Cerebral metabolism and neural function. Williams and Wilkins, Baltimore. In press.
QUISTORFF, B., GJEDDE, A. \& HANSEN, A. J. 1979. Spatial analysis of the freeze trapped brain provides for temporal resolution of an event. Metabolic, electrical and blood flow changes during spreading depression. Acta Physiol Scand 105: 42A.

REIVICH, M., SOKOLOFF, L., KENNEDY, C. \& DES ROSIERS, M. 1975. An autoradiographic method for the measurement of local glucose metabolism in the brain. In: Brain work (ed. D. H. Ingvar and N. A. Lassen), pp. 377-384. Munksgaard, Copenhagen

RUBIO, R., BERNE, R. M., BOCKMAN, E. L. \& CURNISH, R. R. 1975. Relationship between adenosine concentration and oxygen supply in rat brain Am J Physiol 228: 1896-1902.

SAGE, J. I. \& DUFFY, T. E. 1979. Pentobarbital anesthesia: Influence on amino acid transport across the blood-brain barrier. J Neurochem 33: 963-965.

SAKURADA, O., KENNEDY, C., JEHLE, J., BROWN, J. D., CARBIN, G. L. \& SOKOLOFF, L. 1978. Measurement of local cerebral blood flow with iodo $\left[{ }^{11} \mathrm{C}\right]$ antipyrine. Am J Physiol 234: H59-H66.

SHINOHARA, M., DOLLINGER, B., BROWN, G., RAPOPORT, S. \& SOKOLOFF, L. 1979. Changes in local cerebral glucose utilization during and following recovery from spreading cortical depression. Science 203: 188-190.

SOKOLOFF, L., REIVICH, M., KENNEDY, C., DES ROSIERS, PATLAK, C. S., PETTIGREW, K. D., SAKURADA, O. \& SHINOHARA, M. 1977. The $\left[{ }^{14} \mathrm{C}\right]$ deoxyglucose method for the measurement of local cerebral glucose utilization: Theory, procedure, and normal values in the conscious and anesthetized albino rat. J Neurochem 28: 897-916.

ŠRAMKA, M., BROŽEK, G., BUREŠ, J. \& NÁDVORNIK, P. 1977/78. Functional ablation by spreading depression: Possible use in human stereotactic neurosurgery. Appl Neurophysiol 40: 48-61.

TSCHIRGI, R. D., INANAGA, K., TAYLOR, J. L., WALKER, R. M. \& SONNENSCHEIN, R. R. 1957. Changes in cortical $\mathrm{pH}$ and blood flow accompanying spreading cortical depression and convulsion. Am J Physiol 190: 557-562.

VAN HARREVELD, A. \& STAMM, J. S. 1952. Vascular concomitants of spreading cortical depression. J Neurophysiol 15:487-496.

VAN HARREVELD, A. \& OCHS, S. 1957. Electrical and vascular concomitants of spreading depression. Am J Physiol 189: 159-166.

VYSKOČIL, F., KŘÍŽ, N. \& BUREŠ, J. 1972. Potassium-selective microelectrodes used for measuring brain potassium during spreading depression and anoxic depolarization in rats. Brain Res 39: 255-259. 